\title{
Stigma dan Diskriminasi Orang Dengan HIV/AIDS (ODHA) pada Pelayanan Kesehatan di Kota Pekanbaru Tahun 2014
}

\section{Stigmatization and Discrimination People Living With HIV / AIDS (PLWHA) At Pekanbaru Health Service In 2014}

\section{Riri Maharani}

Program Studi Ilmu Kesehatan Masyarakat, STIKes Hang Tuah Pekanbaru

\begin{abstract}
ABSTRAK
Stigma dan diskriminasi masih sering terjadi pada orang dengan HIV/AIDS (ODHA). Wawancara yang dilakukan kepada beberapa orang yang bergerak di lembaga penggagas ODHA di kota Pekanbaru ( sebagian dari mereka adalah ODHA) mengatakan bahwa mereka pernah mengalami adanya stigma dan diskriminasi. Penelitian ini bertujuan untuk diketahuinya informasi tentang stigma dan diskrimiasi terhadap ODHA pada palayanan kesehatan di Kota Pekanbaru tahun 2014. Jenis penelitian yang digunakan adalah kualitatif dengan rancangan pendekatan fenomenologi. Informan dalam penelitian ini adalah ODHA sebanyak 3 orang dan petugas kesehatan sebanyak 5 orang. Pengumpulan data dilakukan dengan wawancara mendalam dan telusur dokumen. Hasil penelitian diperoleh bahwa isu stigma penyakit HIV/AIDS yang didengar oleh ODHA pada pelayanan kesehatan adalah jenazah pasien HIV/AIDS dibungkus dengan plastik dan dimasukkan kedalam peti, kasur dan semua peralatan bekas pasien HIV/AIDS dibuang dan dibakar, penggunaan alat pelindung diri yang berlebihan. Diskriminasi terhadap ODHA meliputi dilecehkan secara lisan, pemberian kode pada status pasien HIV, tempat pembuangan sampah yang masih dibedakan, pelayanan kesehatan yang tidak memadai/lambat, pelayanan yang berbeda, penggunaan alat pelindung yang berlebihan, diisolasi, serta melakukan tindakan medis tanpa memberikan informed consent. Kesimpulan dalam penelitian ini adalah stigma dan diskriminasi terhadap ODHA pada pelayanan kesehatan masih sering terjadi, stigma dan diskriminasi ODHA pada pelayanan kesehatan dimulai dari pendaftaran/IGD, rawat inap, ruang operasi sampai di ruang jenazah. Peningkatan promosi kesehatan yang terencana dan berkesinambungan dalam upaya penghilangan stigma dan diskriminasi terhadap ODHA pada pelayanan kesehatan dan kegiatan advokasi kepada pemegang kebijakan di sektor kesehatan.
\end{abstract}

Kata Kunci : Stigma, Diskriminasi, ODHA, Pelayanan Kesehatan

\section{ABSTRACT}

Stigmatization and discrimination are still common in people with HIV / AIDS (PLWHA). Interview do many people to work in agency institute of PLWHA in the Pekanbaru city (most of them are PLWHA) said that they ever experienc stigmatization and discrimination. This study was conducted to information about stigmatization and diskrimination on health in the Pekanbaru city of 2014. This research design is qualitative with a phenomenological approach. Informants in this study is 3 people PLWHA and health officials is 5 people. Data was collected through in-depth interviews and document search. The results of this study showed that the issue of the stigma disease of HIV / AIDS are heard by PLWHA to health services is the body people with HIV / AIDS wrapped in plastic and put into crates, mattresses and all appliances former patients of HIV / AIDS discarded and burned, the use of personal protective equipment excessive. Discrimination of PLWHA include verbally abused, coding on status HIV patients, landfills are still distinguishable, inadequate health care / slow, different services, excessive use of protective equipment, isolated, and perform medical acts without giving informed consent. The conclusion of this study is the stigmatization and discrimination PLWHA in health care is still often the case, stigmatization and discrimination PLWHA in health care starts from the registation / emergency room, inpatient, operating room up in the mortuary. Suggestion increase health promotion in a planned and sustainable removal efforts of PLWHA stigmatization and discrimination in health services and advocation to policy makers in the health sector.

Keywords: Stigmatization, Discrimination, People with HIV, Health Care

\section{PENDAHULUAN}

Stigma adalah prasangka memberikan label sosial yang bertujuan untuk memisahkan atau mendiskreditkan seseorang atau sekelompok orang dengan cap atau pandangan buruk. Dalam prakteknya, stigma mengakibatkan tindakan diskriminasi, yaitu tindakan tidak mengakui atau tidak mengupayakan pemenuhan hak-hak dasar individu atau kelompok sebagaimana selayaknya sebagai manusia yang bermartabat. Stigma dan diskriminasi masih sering terjadi pada orang dengan HIV/AIDS (ODHA) (Kemenkes RI, 2012). 
Berdasarkan data dari DINKES Propinsi Riau tahun 2013 bahwa jumlah kasus penderita HIV di 12 Kabupaten/Kota, Pekanbaru merupakan jumlah penderita terbanyak yaitu 482 kasus HIV dan 521 kasus AIDS. Jumlah penderita HIV/AIDS ini selalu bertambah jika dibandingkan dari tahun sebelumnya yaitu tahun 2012 sebanyak 289 kasus HIV dan 389 kasus AIDS. Dilihat dari jumlah kasus HIV/ AIDS dari tahun ketahun, jumlah kasus AIDS selalu lebih tinggi dibandingkan dengan kasus HIV, ini menandakan bahwa permasalahan tentang HIV/AIDS ini belum semua dapat dikendalikan.

Salah satu kendala dalam pengendalian penyakit HIV/AIDS adalah stigma dan diskriminasi terhadap penderita HIV/AIDS (ODHA). Stigma dan diskriminasi terkait HIV bertahan sebagai hambatan utama untuk HIV yang efektif respon di semua bagian dunia, dengan survei nasional menemukan bahwa diskriminasi pengobatan orang yang hidup dengan HIV terus terjadi dibeberapa aspek kehidupan, termasuk akses ke perawatan kesehatan (UNAIDS, 2013).

Kota Pekanbaru mempunyai beberapa rumah sakit yang telah ditetapkan sebagai tempat pelayanan pengobatan bagi ODHA, yaitu : Rumah Sakit Jiwa Tampan, Rumah Sakit Umum daerah Arifin Achmad dan Rumah Sakit Santa Maria. Begitu juga tempat pelayanan kesehatan seperti puskesmas dan tempat praktek dokter juga harus memberikan pelayanan kesehatan kepada ODHA yang datang konsultasi dan berobat. Puskesmas Payung Sekaki termasuk salah satu puskesmas yang mempunyai klinik VCT yang memberikan pelayanan pada orang yang mempunyai faktor resiko penyakit HIV/ AIDS tersebut.

Wawancara yang dilakukan kepada beberapa orang yang bergerak di lembaga penggagas ODHA di Kota Pekanbaru (sebagian dari mereka adalah ODHA) mengatakan bahwa mereka mendapatkan laporan dari ODHA yang mereka bina pernah mengalami adanya stigma dan diskriminasi yang mereka rasakan pada saat berobat di tempat pelayanan kesehatan, antara lain: tidak diterima menjadi pasien setelah memperkenalkan jati dirinya, pemberian label nama yang mengidentifikasikan seseorang sebagai HIV positif, penggunaan kata-kata dan bahasa tubuh yang negatif dan akses yang terbatas untuk fasilitas rumah sakit.

Tujuan penelitian adalah untuk mengetahui informasi tentang stigma dan diskriminasi terhadap ODHA pada palayanan kesehatan di Kota Pekanbaru tahun 2014.

\section{METODE}

Penelitian ini menggunakan metode kualitatif dengan model fenomenologi yaitu mendeskripsikan bagaimana pengalaman seseorang dan apa maknanya bagi mereka (ODHA). Pengumpulan informasi dalam penelitian ini menggunakan konsep emergent design, artinya rencana dan cara pengumpulan informasi dapat mengalami perubahan dan berkembang berdasarkan fakta di lapangan. Informan dalam penelitian ini adalah ODHA dan petugas kesehatan yang ada di kota Pekanbaru. ODHA sebagai informan utama dan petugas kesehatan (dokter, bidan dan perawat) sebagai informan pendukung. Teknik pengambilan informan dalam penelitian ini diambil berdasarkan purposive sampling. Pada penelitian ini terdapat jumlah informan 8 orang, terdiri dari : 3 ODHA sebagai informan utama dan 5 orang petugas kesehatan sebagai informan pendukung. Jenis data terdiri atas data primer dan data sekunder. Data primer diperoleh dengan melakukan wawancara mendalam. Sedangkan data sekunder adalah data profil tempat penelitian, SOP pengelolaan pasien disalah satu rumah sakit yang menjadi tempat penelitian. Instrumen utama dalam rangka pengumpulan informasi pada penelitian ini adalah peneliti sendiri. Analisa data dilakukan secara kualitatif.

\section{HASIL}

\section{Isu Stigma terhadap ODHA Dalam Pelayanan Kesehatan}

Pada penelitian ini, isu stigma penyakit HIV/AIDS yang didengar oleh ODHA pada pelayanan kesehatan adalah pasien HIV/AIDS jika meninggal di rumah sakit wajib dibungkus dengan plastik dan dimasukkan ke dalam peti, kasur dan semua peralatan bekas pasien HIV/AIDS dibuang dan dibakar, penggunaan alat pelindung diri yang berlebihan seperti penggunaan pakaian menyerupai pakaian astronot baik itu diruang operasi dan ruang jenazah; penggunaan sarung tangan/ handscoon sampai 3 lapis. Seperti penuturan berikut ini :

"Oh,kalo pasien HIV meninggal,nanti akan diplastikin" Isu itu saya dengar 2 tahun belakangan ini, bahwa sesuai dengan standar SOP katanya bahwa pasien HIV yang meninggal diplastikin kemudian dimasukin peti, itu juga saya pernah dapat waktu pelatihan di Surabaya, dan melihat video juga, pasien HIV diplastikin dan dipeti lalu dibawa pulang"

..."Kasurnya dibakar, pokoknya semua semuanya dibakar, itu yang paling seram yang saya dengar"

..."Di ruang operasi petugas kesehatan menggunakan pakaian seperti astronot kalau mengoperasi pasien HIV/AIDS .(Informan 2)

"Pake handscoon 3 lapis kalau menangani pasien HIV/AIDS dan memandikan jenazah juga pake baju astronot" Informan 3 
Pernyataan diatas didukung oleh petugas kesehatan di salah satu rumah sakit yang menyatakan bahwa diruang operasi petugas wajib menggunakan pakaian khusus yang menyerupai pakaian astronot, serta dikamar jenazah untuk menangani jenazah pasien HIV/AIDS. Tindakan tersebut ditetapkan sebagai tindakan pengamanan/safety bagi petugas. Begitu juga jenazah pasien yang telah disetujui untuk dimandikan di rumah sakit wajib untuk dibungkus dengan plastik dan dimasukkan kedalam peti. Seperti penuturan berikut ini :

"Yaaa,,kalau yang gituan,,diruang operasi harus"..."Karena kan penyakit HIV salah satu penularannya adalah melalui darah,,nah kalo mereka operasi kan mengeluarkan darah tu, jadi mau nggak mau harus memakai pakaian seperti itu (pakaian astronot)...yaa yang pastinya untuk safety nya" (Informan 4)

"Semua pasien yang meninggal disini semuanya harus dimandiin, tapi paling bedanya pasien HIV disini dikamar jenazah langsung dibungkus, jadi dirumah nggak diapa - apain lagi"..." rata - rata pasien HIV yang meninggal baik dia muslim atau non muslim itu diplastikin dan dipetiin..supaya tidak menularkan dengan yang lain" (Informan 6)

Penuturan dari informan lainnya mengatakan isu stigma dipelayanan kesehatan juga menganggap orang yang positif HIV itu adalah orang yang tidak benar, wanita yang positif HIV tidak boleh punya anak, dan penolakan terhadap akses pelayanan kesehatan. Seperti kutipan berikut :

"Jadi kalo tau kami adalah positif HIV, pikiran orang pasti beranggapan yang nggak benar, dia harus diungsikan disuatu tempat, terus kalo aku bilang, mereka baik didepannya, tapi kita nggak bisa membohongin matanya,atau bahasa tubuh yang lebih menjauh, begitulah yang aku dengar di pelayanan kesehatan" (Informan 3)

Berikut ini merupakan bentuk stigma internal atau stigmatisasi diri yang dialami oleh beberapa ODHA tentang statusnya yang HIV positif, mereka menganggap HIV itu adalah penyakit orang yang berperilaku jelek, sehingga mereka takut untuk berbicara jujur kepada siapa pun karena takut akan konsekuensinya misalnya merasa menjatuhkan harga dirinya sendiri, memiliki rasa rendah diri karena status HIV tersebut dan mengundurkan diri dari tempat kerja karena mereka takut diketahui sebagai ODHA. Seperti kutipan berikut ini :

"Kalau seperti ini saya minta dikoskan saja,,,saya merasa diasingkan langsung"

..."Dulu saya bekerja di tempat lain, tapi karena tau status ini saya mengundurkan diri dari tempat kerja saya"..."saya sakit mbak jadi pengen istirahat aja"..."saya jawab dengan berbohong bahwa saya tidak terkena HIV, saya hanya kecapean, kalo mbak dewi nggak percaya,ayo kita sama sama cek darah saya dan liat hasilnya" (Informan 1)

"Nggak mau buka status, karena pada waktu itu aku berpikir kalo aku memberi tahu status ku itu sama namanya aku membunuh diri ku sendiri" ( Informan 3)

Dalam penelitian ini ditemukan suatu ungkapan ODHA yang menyadari bahwa perasaan stigma internal yang dialami oleh para ODHA dikarenakan rasa sensitivitas ODHA yang tinggi. Seperti penuturan berikut ini :

"Aku tidak terlalu merasa adanya stigma dan diskriminasi pada diri aku, karena aku orangnya nggak sensitif,,karena orang merasa adanya diskriminasi dilihat dari sisi kitanya sendiri, kalo aku merasa,orang yang positif HIV ini rasa sensitivitasnya itu tinggi, apalagi orang gini,,,kadang orang itu melihat aku kok gitu terus merasa pula,tapi mungkin karena aku orangnya cuek jadi ya biasa - biasa saja” (Informan 3)

Tidak hanya ODHA yang mendengar isu stigma mengenai penyakit HIV/AIDS ini, tetapi petugas kesehatan juga mengalami demikian. Sebelum mendapatkan pelatihan, petugas beranggapan bahwa penyakit HIV/AIDS itu adalah penyakit yang menakutkan/ monster. Seperti penuturan berikut ini :

"Kalo pada awalnya, kita karena belum tau apa itu HIV,hanya mungkin mendengarkan HIV itu sudah mengatakan itu adalah monster, pada awalnya, tetapi karena kita sudah diberi ilmu dan juga pelatihan dan melihat kenyataannya, bahwa HIV itu tidak menakutkan, hanya perilakunya yang mau kita ubah untuk mau berperilaku yang sehat kepada masyarakat" (Informan 5)

Meskipun telah mendapatkan pelatihan, namun masih ada petugas kesehatan yang merasa cemas ketika berhadapan dengan pasien HIV/ AIDS terutama di ruang rawat inap. Seperti penuturan berikut ini :

"Yaaa pada saat menangani pasien HIV/AIDS perasaan cemas pasti adalah,, karena kita tidak tau pori - pori tangan kita terluka..tubuh kita terluka, sendal kita, mungkin pada saat operasi kita kejatuhan cairan darah, cairan ketuban yang pada saat secsio itu biasanya muncrat tu...tetap kita ada cemas dalam menanganinya" (Informan 7)

"Malah ada orang yang sudah pelatihan (menyebutkan petugas kesehatan lain), sama 
duduk aja dia tidak mau..hmm ntahlah nggak ngerti juga itu" (Informan 5)

\section{Diskriminasi Pada ODHA Dalam Pelayanan Kesehatan}

Dalam penelitian ini ditemukan berbagai macam bentuk diskriminasi yang diterima oleh ODHA maupun keluarga serta teman sesama ODHA yang dirawat dirumah sakit. Ada yang dilecehkan secara lisan dengan menyebut penyakit HIV dengan nada yang lantang, pemberian kode pada status pasien HIV, tempat pembuangan sampah yang masih dibedakan, pelayanan kesehatan yang tidak memadai/lambat dalam menindak lanjutin tindakan terhadap ODHA, pelayanan yang berbeda (perbedaan perlakuan pada pasien saat menjalankan perawatan meskipun sudah memilih ruang VIP, pemberian makan dibawah pintu, seprai tidak diganti-ganti) dan penggunaan alat pelindung yang berlebihan, diisolasi, serta melakukan tindakan medis tanpa memberikan informed consent sebelum tindakan dilakukan (vasektomi secara paksa pada pasien yang melahirkan dengan tindakan operasi section cesar dan pemeriksaan darah). Seperti penuturan berikut ini :

"Keesokan harinya,,diruang rawat baru saya merasakan adanya stigma dan diskriminasi dari perawatnya"..."kalau pergantian shift perawat dengan dokter,,kepala perawatnya kan ikut juga,,,dokternya sambil periksa kan nanya sama kepala perawatnya,",ini pasien penyakit apa??", "Perawatnya langsung jawab dengan nada yang lantang "PASIEN HIV"atau pasien $H I V$ digabung cara bacanya,kan biasanya untuk pasien HIV kan ada kodenya biasanya B20, selama 6 hari saya digitukan (menjawab sambil melihatkan nada kesalnya)"

..."Tempat pembuangan sampah kami masih dibedakan dan diberi kode B20"..." kalau berobat di RSUD, apalagi diruang VCT, langsung suka memvonis orang mati (menjawab dengan nada kesal)..itu kejadian,, keODHA temannya saya langsung...berkata kuat - kuat tanpa memperhatikan perasaan orang" (Informan 1)

"Saya merasa waktu suami saya sakit itu, mulai dari awal masuk rumah sakit,, petugas kesehatan disitu memperlakukan dia berbeda"..."Mulai dari masuk UGD"..." Waktu dirawat diruang VIP juga masih dibedain, kalau kita pengen pelayanan yang gimana, pasti kita milih ruangan yang VIP, tapi saya merasa sama aja kok, karena ketika saya bandingkan dengan teman - teman yang di bangsal kok hampir sama aja, nggak ada dokternya juga, perawatnya masuk kayak orang ketakutan, pakai baju astronot, terus didepan pintu kamar itu..(sambil dengan nada suara keras dan mata yang berkaca - kaca) cuman di depan kamar dia aja, disediakan baskom, pokoknya ada semua, khusus semuanya peralatan dia"..." petugas yang antar makanan, ngantar makanannya cuman sampai depan pintu kamar aja, tidak berani masuk" (Informan 2)

Tidak semua petugas kesehatan telah terpapar informasi tentang HIV dan AIDS dengan benar, sehingga menyebabkan petugas kesehatan mendiskriminasi pasien ODHA yang bermasalah pada giginya. Seperti yang dialami oleh informan berikut ini:

"Waktu saya pergi kedokter gigi, jadi pas saya duduk dikursi pelayanannya,ibuk itu kan pegang status RM saya,tanpa sengaja dia liat kode nomornya saya,langsung berubah ekspresinya terkejut melihat kode itu,(saya liat sendiri ekspresinya berubah), dokter itu tiba - tiba menoleh kekamar belakang membilang keperawatnya,"heeehhh kok nggak bilang itu pasien HIV dengan suara agak berbisik, kemudian dia balik lagi,, dia pake sarung tangan, pakai kaca mata, terus pakai masker juga, disuruhnya saya membuka mulut,,kemudian dilihatnya,,,Oh ini nggak pa pa...(padahal waktu itu gigi saya berlobang,,jadi niat mau dicabut biar nggak sakit lagi),,tetapi nadanya ketus seperti mau marah marah,padahal awalnya ramah - ramah aja,,bilang gini "liat giginya,,hmmm nggak pa pa ini,,,Tapi kan buk saya dirujuk tadi disini disuruh cabut buk, "siapa bilang, "Nggak pa pa kok", Kan saya yang dokter gigi,,bukan mereka...ya sudah sana keluar"..."Waktu anak teman saya yang positif HIV mau cabut gigi ke dokter gigi, dokter itu suruh cepat - cepat buka mulutnya,langsung dicabut tanpa ada disuruh kumur - kumur, "yaa namanya anak kecil pasti nangis yaa mbak", "sudah sana", "jangan nangis", "sana pulang”.kata dokter itu...langsung dikasih kapas pulang" (Informan 2)

Diskriminasi tidak hanya terjadi pada pelayanan pasien HIV/AIDS yang ingin mendapatkan perawatan karena sakit, tetapi diskriminasi juga didapati ketika perlakuan terhadap jenazah pasien HIV/AIDS dan biaya yang berbeda yaitu biaya lebih besar dari pada jenazah yang bukan HIV/ AIDS. Seperti penuturan berikut ini :

"Kalau ada orang positif HIV meninggal, memandikan dirumah sakit biayanya beda, kalau orang yang positif 2 juta, kalau orang nggak ketahuan statusnya, bisa jadi positif bisa jadi nggak itu hanya 300 ribu rupiah, selain itu kalau orang positif, dipakaikan plastik, padahal itukan 
nggak perlu"..."Kalau dah memandikan jenazah pasien HIVIAIDS langsung pakai jas hujan (sambil ketawa,,karena mereka anggap lucu aja kok ampe ketakutan seperti itu), kalau memandikan jenazah pasien biasa mereka nggak protektif, tapi kan belum tentu dia nggak positif, (sambil melihatkan foto orang dikamar jenazah yang lagi memandikan kepada saya)" (Informan 3)

\section{PEMBAHASAN}

\section{Isu Stigma terhadap ODHA Dalam Pelayanan Kesehatan}

Isu merupakan kabar yang tidak jelas tetapi menyebar ditengah masyarakat atau masalah yang dikembangkan untuk ditanggapi. Isu stigma ODHA dalam pelayanan kesehatan sering terdengar dalam kehidupan kita sehari-hari, lembaga yang diharapkan memberikan perawatan dan dukungan, pada kenyataannya merupakan tempat pertama orang mengalami stigma dan diskriminasi. Misalnya, memberikan mutu perawatan medis yang kurang baik, menolak memberikan pengobatan, seringkali sebagai akibat rasa takut tertular yang salah kaprah (Kesrepro, 2007).

\section{Jenazah ODHA dibungkus plastik dan dimasukkan kedalam peti}

Hal ini sesuai dengan pedoman perawatan jenazah di kamar jenazah (dikutip dari Pedoman Tatalaksanaan Klinis Infeksi HIV di Sarana Pelayanan Kesehatan'halaman 198-199, terbitan PPM \& PL Depkes 2001), bahwa jenazah yang telah selesai dimandikan, kemudian dibungkus dengan kain kafan atau pembungkus lain sesuai dengan agama dan kepercayaan yang dianut. Jenazah yang telah dibungkus tidak boleh dibuka lagi (Spiritia, 2006). Oleh karena itu, sebaiknya petugas di ruang jenazah memberikan informasi dan pemahaman terlebih dahulu kepada keluarga pasien yang mau dimandikan di rumah sakit.

\section{Semua peralatan termasuk kasur bekas ODHA dibuang dan dibakar}

Penuturan dari petugas kesehatan yang peneliti wawancarai, bahwa semua peralatan bekas ODHA termasuk kasur tidak dibuang dan dibakar lagi, karena apabila semua peralatan bekas ODHA dibuang akan membuat rumah sakit menjadi rugi dari segi sarana dan prasarana. Peralatan yang dibuang dan dibakar tergantung dari jenis alat yang dipakai saja. Karena dirumah sakit sekarang sudah menggunakan peralatan bahan sekali pakai (disposible) seperti sarung tangan, alat suntik, dan alat pelindung diri yang terbuat dari plastik. Untuk kasur bekas ODHA cukup dijemur saja, sedangkan seprai dan instrumen lainnya yang digunakan untuk pasien ODHA diproses dengan urutan: dekontaminasi, pembersihan, desinfeksi atau sterilisasi. Ketetapan proses ini juga ada di buku panduan pencegahan infeksi untuk fasilitas pelayanan kesehatan dengan sumber daya terbatas.

\section{Penggunaan alat pelindung diri yang berlebihan}

Penuturan yang disampaikan oleh petugas kesehatan di salah satu rumah sakit Kota Pekanbaru bahwa diruang operasi petugas wajib menggunakan pakaian khusus yang menyerupai pakaian astronot. Tindakan tersebut ditetapkan sebagai tindakan pengamanan/ safety bagi petugas saja. Penggunaan sarung tangan ganda/ berlapis - lapis, masker, pisor atau goggles, apron, gaun penutup dan gaun bedah semata - mata digunakan untuk perlindungan fisik tubuh sebagai ketetapan standar pencegahan infeksi (Sarwono, 2005).

\section{Anggapan Bahwa ODHA adalah Orang Yang Tidak} Benar

Petugas kesehatan masih beranggapan bahwa ODHA adalah orang yang tidak benar. Masyarakat juga beranggapan bahwa "jahat" dilihat dari perilaku sek bebas, tapi masyarakat belum memahami termasuk petugas kesehatan yang belum bisa menerima bahwa virus HIV ini ditularkan bukan hanya karena "perilaku jahat"/ "perilaku tidak benar", melainkan karena melalui transfusi darah, jarum suntik, dan dari suami HIV ke istri sebagai wanita yang baik-baik. Pada saat yang sama masyarakat menyalahkan ODHA sebagai sumber penularan penyakit AIDS. Pandangan dan pendapat masyarakat begitu juga petugas kesehatan tentang HIV/AIDS yang akhirnya menimbulkan stigma terhadap ODHA.

\section{Wanita yang Positif HIV tidak Boleh Punya Anak}

Dikutip dari buku yang ditulis oleh Burns et al, (2005) bahwa kehamilan bisa berbahaya bagi ibu yang positif HIV atau mengidap AIDS. Dimasa hamil dan persalinan, ia lebih rentan terhadap masalah keguguran, demam, infeksi, daya tahan merosot, dan terjadinya infeksi - infeksi berat yang sulit diatasi dan dapat mengancam jiwa jika dibandingkan dengan ibuibu lain yang bebas HIV/AIDS. Selain itu, bayinya pun mungkin akan tertular HIV sejak lahir, lahir terlalu dini atau sakit-sakitan lalu meninggal. Memang lebih aman bagi ibu maupun bayi bila kehamilan bisa dicegah sejak sang ibu terbukti positif HIV.

\section{Penolakan Terhadap Akses Pelayanan Kesehatan}

Hal ini sebenarnya tidak boleh terjadi lagi. Karena setiap petugas kesehatan yang memberikan pelayanan kesehatan kepada semua pasien baik itu pasien HIV/AIDS atau bukan pasien HIV/AIDS sudah 
mempunyai kewaspadaan universal dalam menghadapi pasien. Sebagian dari petugas kesehatan juga sudah diberi pelatihan dalam menghadapi pasien HIV/AIDS. Namun hal ini tidak menjadi patokan, karena masih ada petugas kesehatan yang merasa cemas jika berhadapan dengan pasien HIV tersebut. Kecemasan petugas tersebut diakibatkan karena perkembangan isu tentang penularan HIV/AIDS tersebut.

\section{Diskriminasi Pada ODHA Dalam Pelayanan Kesehatan}

Dalam prakteknya, stigma mengakibatkan tindakan diskriminasi, yaitu tindakan tidak mengakui atau tidak mengupayakan pemenuhan hak-hak dasar individu atau kelompok sebagaimana selayaknya sebagai manusia yang bermartabat (Kemenkes RI, 2012).

\section{Pemberian Kode Pada Status Pasien ODHA}

Pemberian kode pada status pasien/rekam medis merupakan satu rangkaian kegiatan yang penting dalam suatu rumah sakit. Begitu juga pada pasien HIV/AIDS yang diberi kode B-20 dan cap istimewa, dimaksudkan untuk memudahkan petugas kesehatan dalam memberikan pelayanan kepada pasien tersebut.

\section{Tempat Pembuangan Sampah yang Masih dibedakan}

Penuturan ODHA menyatakan bahwa mereka mengganggap tempat pembuangan sampah yang masih dibedakan merupakan diskriminasi yang mereka rasakan. Tetapi hal ini ditanggapi oleh petugas kesehatan yang menyatakan bahwa pembedaan itu dimaksudkan untuk memberi kemudahan dalam pengelolaan sampah akhir. Beberapa sampah fasilitas kesehatan terkontaminasi. Jika tidak dikelola secara benar, sampah terkontaminasi yang membawa mikroorganisme ini dapat menular pada petugas yang kontak dengan sampah tersebut termasuk masyarakat pada umumnya. Sampah bekas pasien HIV/AIDS digolongkan sebagai sampah terkontaminasi. Pengelolaan sampah terkontaminasi disalah satu rumah sakit di Kota Pekanbaru ini adalah dilakukan insinerasi.

\section{Petugas Kesehatan Menggunakan APD yang Berlebihan}

Penuturan petugas kesehatan bahwa mereka menggunakan alat pelindung diri yang dianggap ODHA berlebihan bukan untuk mendiskriminasi tetapi sudah menjadi ketetapan standar pencegahan infeksi untuk fasilitas pelayanan kesehatan. Misalnya : penggunaan sarung tangan ganda terutama diruang operasi, penggunaan sarung tangan panjang bila memandikan jenazah pasien baik pasien ODHA atau bukan ODHA, seperti yang dijelaskan pada SOP pengelolaan pasien yang mendapat perhatian khusus curiga AIDS.

\section{Pelecehan Secara Lisan}

Dilecehkan secara lisan dengan menyebut penyakit HIV dengan nada yang lantang. seharusnya tidak terjadi karena perlakuan demikian akan membuat pasien merasa tidak nyaman. Secara psikologis orang dengan HIV/AIDS memiliki rasa sensitivitas yang tinggi. Jadi petugas harus memiliki kemampuan komunikasi yang baik, sesuai dengan standar pelayanan pada pasien di ruang VCT.

\section{Tidak Melakukan Pemberian Informed Consent Sebelum Melakukan Tindakan}

Seharusnya, sesuai dengan kode etik kedokteran, seorang dokter harus memberikan informed consent sebelum tindakan dilakukan. Apalagi dalam pengambilan darah untuk tes HIV, bahwa tes HIV hanya boleh dilakukan : atas izin pasien sendiri, didahului dan diakhiri dengan bimbingan dan konseling, serta hasil tes langsung disampaikan kepada yang bersangkutan langsung tanpa ada perantara (Burns et al, 2005).

\section{Perbedaan Perlakuan Pada Pasien ODHA}

ODHA pernah mendapatkan perlakuan yang berbeda pada pelayanan dokter gigi. Ketika hal ini dicroscheck dengan salah satu dokter gigi, mereka mengatakan bahwa tidak semua dokter gigi yang menolak pasien dengan HIV/AIDS. Itu tergantung dari kesiapan dokter gigi apakah siap untuk melayani pasien ODHA tersebut. Ada yang menolak secara halus dengan cara merujuk pasien ketempat lain. Hal ini mereka lakukan karena menganggap pasien HIV/AIDS adalah orang mempunyai resiko besar jika ingin mencabut gigi. Karena langsung berhubungan dengan darah dan air liur ODHA. pada standarnya yang penting setiap pelayanan yang diberikan jangan lupa kewaspadaan universal dan ketetapan standar pelayanan kedokteran gigi yang telah ditetapkan. Perlakuan pelayanan kesehatan itu seharusnya tidak terjadi, karena kita sebagai petugas kesehatan harus memperlakukan pasien sama semua sesuai dengan kode etik profesi yang dimiliki oleh petugas layanan kesehatan.

Isolasi

Isolasi yang dilakukan khusus untuk pasien yang mempunyai penyakit yang menular misalnya : HIV/AIDS dulunya memang ada. Namun saat ini tidak terjadi lagi, seperti yang disampaikan oleh petugas kesehatan di salah satu rumah sakit bahwa pasien HIV/AIDS yang dirawat dirumah sakit tersebut ruang perawatannya sudah disamakan dengan pasien bukan HIV/AIDS. Pemisahan perawatan pada pasien HIV 
dengan pasien lainnya seharusnya tidak terjadi. Karena virus HIV tidak menular ketika berada pada satu ruangan, bersenggolan, dan bersalaman dengan pasien HIV.

\section{KESIMPULAN}

Isu stigma penyakit HIV/AIDS yang didengar ODHA dalam pelayanan kesehatan di kota pekanbaru adalah pasien HIV/AIDS jika meninggal di rumah sakit wajib dibungkus dengan plastik dan dimasukkan kedalam peti, kasur dan semua peralatan bekas pasien HIV/AIDS dibuang dan dibakar, penggunaan alat pelindung diri yang berlebihan seperti penggunaan pakaian menyerupai pakaian astronot baik itu di ruang operasi dan ruang jenazah; penggunaan sarung tangan/ handscoon sampai 3 lapis, menganggap orang yang positif HIV itu adalah orang yang tidak benar, wanita yang positif HIV tidak boleh punya anak, dan penolakan terhadap akses pelayanan kesehatan.

Diskriminasi yang diterima oleh ODHA maupun keluarga serta teman sesama ODHA yang dirawat dirumah sakit antaralain meliputi dilecehkan secara lisan dengan menyebut penyakit HIV dengan nada yang lantang, pemberian kode pada status pasien HIV, tempat pembuangan sampah yang masih dibedakan, pelayanan kesehatan yang tidak memadai/lambat dalam menindak lanjutin tindakan terhadap ODHA termasuk dipoli gigi, pelayanan yang berbeda (perbedaan perlakuan pada pasien saat menjalankan perawatan meskipun sudah memilih ruang VIP, pemberian makan dibawah pintu, seprai tidak diganti-ganti, dan biaya yang lebih besar untuk pemandian jenazah pasien HIV/AIDS), penggunaan alat pelindung yang berlebihan, diisolasi, serta melakukan tindakan medis tanpa memberikan informed consent sebelum tindakan dilakukan (vasektomi secara paksa pada pasien yang melahirkan dengan tindakan operasi section cesar dan pemeriksaan darah).

\section{SARAN}

Perlu terus digalakkan upaya penghilangan stigma dan diskriminasi terhadap ODHA di kalangan petugas kesehatan dalam memberikan pelayanan kepada pasien HIV/AIDS baik di ruang rawat maupun diruang operasi dengan menetapkan standar pelayanan operasional yang baku dan disertai dengan pelatihan tentang HIV/AIDS (termasuk penggunaan alat-alat yang telah digunakan untuk pasien ODHA) dan penyediaan sarana pendukung yang memadai.

Selain itu, juga perlu melakukan kegiatan advokasi dengan dinas kesehatan dan direktur rumah sakit dalam peningkatan program manajemen mutu pelayanan kesehatan di rumah sakit untuk meningkatkan persepsi petugas kesehatan terhadap
ODHA serta menghilangkan stigma dan diskriminasi oleh petugas kesehatan terhadap ODHA.

\section{UCAPAN TERIMA KASIH}

Ucapan terima kasih ditujukan kepada DR. dr. Toha Muhaimin, M.Sc dan Emy Leonita, SKM, MPH selaku Pembimbing dan Jasrida Yunita, SKM, M.Kes selaku Penguji; Pihak Rumah Sakit dan LSM di kota Pekanbaru tempat penelitian ini dilakukan.

\section{DAFTAR PUSTAKA}

Andrewin Aisha \& Chien Li Yin, (2008). Stigmatization of Patients with HIV/AIDS among Doctors and Nurses in Belize. AIDS Patient Care and STDs. Volume 22, number 11.

Burn August, Lovich Ronnie, Maxwel J, Shapiro K, (2005). Perempuan dan AIDS :Disarikan dari Bila Perempuan Tidak Ada Dokter (INSISTPress). Penerjemah Naomi Omi Intan: Yogyakarta,Oktober 2009.

Butt Leslie, Morin Jack, Numbery G, Peyon I, Goo Andreas, (2010). Stigma dan HIV/AIDS di Wilayah Pegunungan Papua. Kerjasama Penelitian antara Pusat studi Kependudukan UNCEN, Abepura, Papua dan University of Victoria, Canada.

Chen WT, Han, M, \&Holzemer, W.L, (2004).Nurses, attitudes and practice related to HIV transmission in northeastern China, AIDS patient care \&Stds, Volume 18, Number 7.

Dokumen Dinas Kesehatan Propinsi Riau tahun 2013.

Harapan, Feramuhawan, Kurniawan, Anwar, Andalas, danHossain, (2013). HIV-related stigma and discrimination: a study of health care workers in Banda Aceh, Indonesia, (online), diakses 23 November 2013.

Kemenkes RI, (2013a). Laporan Perkembangan HIVAIDS di Indonesia, Triwulan II Tahun 2013. (www.aidsindonesia.or.id), diakses 24 November 2013.

Kemenkes RI, (2012b). Buku Pedoman Penghapusan Stigma dan Diskriminasi Bagi Pengelola Program, Petugas Layanan Kesehatan dan Kader. Bakti Husada.

Kesrepro, (2007). Lawanlah Stigma dan Diskriminasi untuk Memenangi Perang Melawan HIV/AIDS. (http://www.kesrepro.info/?q=node/305, diakses pada 04 Januari 2014).

Lapau, Buchari. (2012). Metode Penelitian Kesehatan; Metode Ilmiah Penulisan Skripsi, Tesis, dan 
Disertasi, Jakarta: Yayasan Pustaka Obor Indonesia, hal 27.

Sarwono, Prawirohardjo, (2005). Panduan Pencegahan Infeksi untuk Fasilitas Pelayanan Kesehatan dengan Sumber Daya Terbatas. Jakarta : Tridasa Printer.

Spiritia, (2009a). Hidup Dengan HIV/AIDS, Seri Buku Kecil. (http://spiritia.or.id) diakses 04 Januari 2014.

Spiritia, (2011b). Laporan Akhir Penelitian Peran Dukungan Sebaya Terhadap Peningkatan Mutu Hidup ODHA Di Indonesia Tahun 2011. (http://spiritia.or.id) diakses 04 Januari 2014.
UNAIDS, (2012a). Global report: UNAIDS report on the global AIDS epidemic 2012. WHO Library Cataloguing-in-Publication Data, (online) diakses 4 Februari 2014.

UNAIDS, (2013b).Global report: UNAIDS report on the global AIDS epidemic 2013. WHO Library Cataloguing-in-Publication Data, (online) diakses 4 Februari 2014.

Yanhai Wan, Ran Hu, Ran Guo, Arnade Linda (2009) Discrimination against People with HIVIAIDS in China. The Equal Rights Review, (online) diakses 04 Januari 2014. 